\title{
MENGUNGKAP FENOMENA BAHASA CAMPURAN PADA BUDAYA POPULER DALAM PERSPEKTIF POSMODERN
}

\author{
Teguh Tri Susanto ${ }^{1,}$ JakaAtmaja $^{2}$, Chepi Nurdiansyah $^{3}$, Nur Alam ${ }^{4}$ \\ ${ }^{1}$ Fakultas Komunikasi dan Bahasa, Universitas Bina Sarana informatika \\ teguh.tht@bsi.ac.id \\ ${ }^{2}$ Fakultas Komunikasi dan Bahasa, Universitas Bina Sarana informatika \\ jaka.jaj@bsi.ac.id \\ ${ }^{3}$ Fakultas Komunikasi dan Bahasa, Universitas Bina Sarana informatika \\ chepi.cnh@bsi.ac.id \\ ${ }^{4}$ Fakultas Komunikasi dan Bahasa, Universitas Bina Sarana informatika \\ nur.nra@bsi.ac.id
}

\begin{abstract}
Abstrak
Globalisasi dengan pesatnya perkembangan teknologi informasi berdampak mencairnya batas sendisendi kehidupan manusia dalam banyak aspek. Salah satu aspek yang paling terdampak adalah kebudayaan. Masuknya budaya global meretas sekat-sekat budaya lokal. Dalam budaya global terjadi pencampuran aneka kebudayaan. Budaya hasil pencampuran tidak bisa lagi disamakan dengan budaya asal. Lahirnya model-model kebudayaan baru kadang-kadang mengejutkan dan sulit difahami. Salah satu unsur kebudayaan yang penting adalah bahasa. Di era tanpa batas ini marak digunakan bahasa campuran. Maraknya penggunaan bahasa campuran bisa dilihat pada budaya populer lirik lagu. Lagu bisa dimaknai sebagai bentuk media komunikasi sekaligus produk budaya. Sebagai unsur kebudayaan bahasa mampu merepresentasikan perubahan-perubahan sosial yang terjadi di tengah-tengah masyarakat penggunanya. Penggunaan bahasa campuran pada lirik lagu menarik untuk diteliti sebagai pintu masuk bagi kajian lebih jauh atas dinamika sosial budaya masyarakat. Pendekatan culture studies dengan perspektif kritis posmodern menggunakan metode analisis wacana menjadi pisau bedah yang digunakan untuk mengungkap hal-hal apa yang menjadi latar, motif atau ideologi penggunaan bahasa campuran dalam lirik lagu. Dari penelitian ini bisa difahami adanya pergulatan budaya antara budaya "superior" terhadap budaya inferior. Dominasi dan hegemoni terjadi secara simbolik yang mana hal tersebut bisa jadi merupakan bahaya laten bagi harmoni dalam keragaman budaya yang ada.

Kata Kunci: Bahasa, Budaya Populer, Posmodern
\end{abstract}

\begin{abstract}
Globalization with the rapid development of information technology increases the boundaries of the joints of human life in many aspects. One of the most affected fields is culture. The entry of global culture to break the barriers of local culture. In global culture there is a mixture of various cultures. The culture of mixing cannot be compared to the culture of origin. The birth of models sometimes fails and is difficult to understand. One important culture is language. In this era without limits, mixed languages are used. Song lyrics The rise of the use of mixed languages can be seen in popular culture. The song can be interpreted as a form of communication media as well as cultural products. As a language culture can not represent social changes that occur in the midst of the user community. The use of mixed languages in song lyrics is interesting for the entrance to further assessment of the socio-cultural development of the community. Research on cultural assessment with a postmodern critical perspective uses the discourse analysis method to become a scalpel that is used to reveal what are the settings, motives or ideologies of using mixed language in song lyrics. From this research, it can be understood the existence of culture against a culture that is "superior" to an inferior culture. Symbolic domination and hegemony occur where this could be dangerously latent for harmony within the existing cultural diversity.
\end{abstract}

Key words: Language, Popular Culture, Postmodern 


\section{PENDAHULUAN}

Kehidupan masa kini berlangsung dalam suasana transformasi kebudayaan dari masyarakat industri ke masyarakat informasi. Perkembangan teknologi digital, memiliki pengaruh yang besar terhadap kebudayaan masyarakat. Banyak hal dalam kehidupan dipengaruhi oleh budaya dalam bentuk budaya populer. Budaya populer mewujud dalam banyak bentuk. Penyebaran budaya populer berlaku cepat dan masif dengan dukungan media digital yang semakin berkembang pesat. Dengan teknologi digital, batas lokal dan global semakin pudar.

Dalam budaya global terjadi pencampuran aneka kebudayaan. Budaya hasil pencampuran tidak bisa lagi disamakan dengan budaya asal. Lahirnya model-model kebudayaan baru kadang-kadang mengejutkan dan sulit difahami. Salah satu unsur kebudayaan yang penting adalah bahasa. Di era tanpa batas ini marak digunakan bahasa campuran. Maraknya penggunaan bahasa campuran bisa dilihat pada budaya populer lirik lagu.

Sebagai bagian dari kebudayaan populer. Lagu-lagu pop tetap mendapatkan tempat di hati penikmat. Hal itu didukung dengan keragaman genre yang ditawarkan industri musik pop, mampu memuaskan selera para penikmat dari berbagai kalangan. Lagu bisa dimaknai sebagai bentuk media komunikasi sekaligus produk budaya populer. Dalam kurun waktu terakhir Kecenderungan penggunaan bahasa campuran pada lagu-lagu populer semakin banyak dengan jenis lagu semakin beragam. Menurut (Wibowo, 2001) bahasa ialah sistem simbol bunyi yang bermakna serta berartikulasi (dihasilkan oleh alat ucap) yang mempunyai sifat arbitrer serta konvensional, yang dipakai sebagai alat berkomunikasi oleh sekelompok manusia untuk melahirkan perasaan serta pikiran. Sedangkan Menurut Saussure dalam (Littlejohn, 2018) Bahasa (language) adalah sebuah sistem baku yang dapat dianalisis terpisah dari kegunaannya dalam kehidupan sehari-hari. Sedangkan pengucapan (parole) adalah kegunaan sebenarnya dari bahasa untuk mencapai tujuan. Sebagai unsur kebudayaan bahasa mampu merepresentasikan perubahan-perubahan sosial yang terjadi di tengah-tengah masyarakat. Kecenderungan penggunaan bahasa campuran disinyalir juga menandai adanya perubahan sosial budaya masyarakat. Menurut Semenik dalam (Ridaryanthi, 2014) Budaya adalah tentang segala sesuatu yang dilakukan manusia, budaya merujuk pada segala hal yang ada pada kehidupan sosial manusia; tata cara kehidupan, aturan, warisan sosial, dan lain sebagainya. Budaya adalah tentang bagaimana kita berbicara, berperilaku, dan lainnya. 
Pada tahun 1970-an ada pergeseran paradigma studi media dari pembacaan teks menjadi pembacaan kebudayaan. Perubahan tersebut dipelopori oleh para pakar di Inggris yang tergabung di dalam Birmingham School. Beberapa pakar tersebut di anataranya Richard Hoggart, Stuart Hall dan Raymond Williams. Mereka memperkenalkan studi budaya pada media.

Kajian Budaya atau dikenal dengan "culture studies", adalah sebuah formasi diskursif, demikian Stuart Hall menyebutnya. Hall dalam (Ida, 2014) menyatakan bahwa kajian budaya adalah "sebuah kluster (formasi) ide-ide, gambaran-gambaran (image), dan praktik-praktik (practices) yang menyediakan cara-cara menyatakan, bentuk-bentuk pengetahuan, dan tindakan yang terkait dengan topik tertentu, aktivitas sosial atau tindakan institusi dalam masyarakat. Seturut dengan pendapat Hall, lirik lagu bisa menjadi kajian dalam culture studies.

McGuigan dalam (Ida, 2014) menyatakan bahwa perkembangan kajian budaya secara profesional dan institusional pada akhirnya membawa pada kondisi yang disebut oleh Stuart Hall sebagai kajian yang mempermasalahkan secara kritis keberadaan 'kekuasaan, sejarah/masa lalu, dan politik (dalam arti luas). Terkait dengan itu, penggunaan bahasa campuran pada lirik lagu, sejauh ini dianggap sebagai sesuatu yang wajar. Bahasa campuran dalam lirik lagu bahkan menjadi trend. Trend yang terjadi ditunjukkan dengan apresisasi masyarakat yang bagus pada lagu-lagu dengan lirik bahasa campuran. Hal itu bisa dibuktikan dengan banyaknya lagu dengan lirik bahasa campuran menjadi hits.

Pendekatan Culture studies relevan untuk digunakan sesuai pendapat (Yusuf, 2016) Culture studies memiliki objek kajian yang luas. Culture studies juga menggunakan berbagai perpektif atau pendekatan dalam mengkaji objek kajiannya (lintas disipliner). Disamping bersifat lintas disipliner, culture studies juga bersifat kritis. Dalam culture studies, realitas fenomena budaya dipersepsi tidak melulu bersifat netral atau steril dari kepentingan (ideologi) serta kuasa. Culture studies salah satu tujuannya adalah membongkar atau membuka selubung kepentingan dan kuasa itu (termasuk dominasi, hegemoni, ideologi, ketidakadilan gender dan sebagainya). Disamping bersifat kritis, culture studies juga bersifat partisipatoris dan emansipatoris dikarenakan kajiannya diarahkan juga untuk menyuarakan suara-suara yang selama ini terpinggirkan dalam teks (media) dan untuk sesuatu yang memiliki dimensi pencerahan, agar masyarakat dapat mengenali dimensi-dimensi yang selama ini disembunyikan dalam teks sehingga mereka tidak terjebak dalam kesadaran palsu 
yang dikembangkan dan dibangun melalui wacana dominan. Terkait dengan adanya dominasi (budaya) Bell dalam (Lubis, 2014) mengutip hipotesis Bourdieu yang menarik bahwa "pada semua masyarakat ada hal/kelompok yang mendominasi dan didominasi dan perbedaan itu pada dasarnya adalah prinsip dasar organisasi sosial. Dapat difahami bahwa dominasi dalam masyarakat dalam berbagai bentuk merupakan hal yang dipandang wajar. Bentuk dominasi (budaya) tersebut bisa saja hadir secara samar dalam bentuk kekerasan simbolik. Terkait dengan dugaan adanya kekerasan simbolik dalam penggunaan bahasa campuran dalam lirik lagu, Bourdieu dalam (Yusuf, 2014) menyatakan bahwa kekerasan simbolik juga merupakan pemaksaan kesewenang-wenangan budaya di mana kekerasan semacam itu implisit dalam hierarki bahasa dan cara penggunaan bahasa. Selanjutnya Bourdieu menyatakan bahwa kekerasan simbolik berjalan dengan membiarkan berbagai representasi yang dominan, opini dan sesuatu yang sudah dianggap benar dan alamiah yang ditanamkan dalam pikiran seseorang. Menurut Yusuf (Yusuf, 2014) Postmodern adalah perubahan budaya (mulai dari gaya hidup hingga paradigma berpikir) yang terjadi sebagai akibat perkembangan ilmu pengetahuan dan teknologi informasi. Dampak dari dinamika yang ada adalah adanya perubahan paradigma modern yang tidak relevan lagi untuk memahami dan menjelaskan kebudayaan yang tengah tumbuh (postmodern). Karena itu, berbagai kritik terhadap aspekaspek kebudayaan dan paradigma modern bermunculan Paradigma baru yang digunakan disebut dengan postmodernisme.

Dalam culture studies banyak teori tokoh-tokoh posmodern yang bisa dijadikan acuan. Baudrillard dalam (Yusuf, 2014) menyatakan bahwa dunia posmodern merupakan dunia peleburan yang dramatis, di mana masalah kelas, etnis, gender, ras, perbedaan politik, ranah sosial dan budaya yang dulunya masing-masing otonom, sekarang saling meleburkan diri, lalu unsur-unsur dan elemen-elemen yang berbeda-beda itu menyatu dan saling berkaitan satu dengan yang lain.

Peran media digital dengan teknologi informasi menjadi alat sekaligus media bagi pergulatan budaya, sesuai yang dinyatakan Kellner dalam (Yusuf, 2014) menyatakan bahwa media informasi, hiburan, komunikasi, memberikan pengalaman yang kuat dan dominan serta melibatkan kehidupan sehari-hari yang dangkal. Pada situasi posmodern individu meninggalkan "gurun realitas" (realitas faktual) dan memasuki ekstase hiperrealitas melalui ranah atau dunia komputer, multimedia serta berbagai pengalaman yang diberikan oleh teknologi baru yang disebut dengan teknologi tinggi. Penggunaan bahasa campuran pada lirik 
lagu menarik untuk diteliti sebagai pintu masuk bagi kajian lebih jauh atas dinamika sosial budaya masyarakat. Pendekatan culture studies dengan perspektif kritis posmodern menggunakan metode analisis wacana menjadi pisau bedah yang digunakan untuk mengungkap hal-hal apa yang menjadi latar, motif atau ideologi penggunaan bahasa campuran dalam lirik lagu.

\section{METODELOGI}

\section{Pendekatan}

Wimmer \& Dominick dalam (Kriyantono, 2014) menyebut pendekatan dengan paradigma, yaitu seperangkat teori, prosedur dan asumsi yang diyakini tentang bagaimana peneliti melihat dunia. Perspektif tercipta berdasarkan komunikasi antar anggota suatu kelompok selama seseorang menjadi bagian kelompok tersebut. Jadi, orang akan mempunyai perspektif tertentu jika dia hidup dalam kelompok dan berinteraksi dengan orang lain. Dalam penelitian ini penulis menggunakan pendekatan kritis. Hidayat dalam (Ronda, 2018) menyatakan bahwa paradigma kritis mendefinisikan ilmu sosial sebagai suatu proses yang secara kritis berusaha mengungkap "the real structures" di balik ilusi, false needs, yang dinampakkan dunia materi, dengan tujuan membantu membentuk suatu kesadaran sosial agar memperbaiki dan merubah kondisi kehidupan manusia. Dalam (Nurhadi, 2017) dijelaskan bahwa paradigma kritis mencoba memahami yang sudah dianggap benar, struktur kekuatan, dan keyakinan atau yang mendominasi masyarakat, dengan pandangan tertentu di mana minat-minat disajikan oleh struktur kekuatan tersebut. Dengan pendekatan ini diharapkan penulis mampu mengungkap latar, motif atau ideologi penggunaan bahasa campuran dalam lirik lagu. Juga Mengungkap dominasi/hegemoni budaya pada lirik lagu dengan bahasa campuran

\section{Metodologi Riset}

Metodologi penelitian yang digunakan adalah kualitatif. Menurut (Sugiyono, 2009), metode penelitian kualitatif adalah penelitian yang digunakan untuk menyelidiki, menemukan, menggambarkan, dan menjelaskan kualitas atau keistimewaan dari pengaruh sosial yang tidak dapat dijelaskan, diukur atau digambarkan melalui pendekatan kuantitatif. 
Menurut (Kriyantono, 2014) Riset kualitatif bertujuan untuk menjelaskan fenomena dengan sedalam-dalamnya melalui pengumpulan data sedalam-dalamnya.

\section{Metode Riset}

Dalam penelitian ini penulis menggunakan metode riset analisis wacana. Menurut (Yusuf, 2016) Analisis wacana merupakan sebuah kajian yang melihat bahasa (wacana) tidaklah kosong dari muatan kepentingan. Oleh karenanya, analisis wacana dalam kajiannya berupaya menyibak atau menyingkap dimensi-dimensi kepentingan dan kekuasaan yang terselubung atau tersembunyi dalam praktik bahasa (media). Analisis wacana sangat berguna pada culture studies terutama dalam mengkaji praktik media. Dari uraian tersebut metode analisis wacana dipandang tepat untuk objek yang diteliti.

\section{PEMBAHASAN}

Penggunaan bahasa campuran pada lirik lagu sebenarnya bukan merupakan hal baru. Misalnya dapat ditemukan campuran bahasa Inggris pada lagu lama berjudul "Kopral Jono" Karya Ismail Marzuki (1914 - 1959).

Aksimu bung very good

Seperti mas Robinhood

Dengan jambulmu

Semua gadis bertekuk lutut

Pada bait lagu karya Ismail Marzuki tersebut, kehadiran kata dalam bahasa Inggris hadir sebagai pemanis dari rima lirik dalam bait tersebut.

Pada masa berikutnya, beberapa lagu dengan bahasa campuran bahasa Indonesia dan bahasa Inggris antara lain: “Kuldesak”(1999) ciptaan Ahmad Dhani

\section{Look A Round I Fly To Find}

A Space To Lay My Head Upon 2x

Aku Bagai Buih Di Laut Biru

Tersapu Ombak Terhempas Badai

Aku Bagai Debu Di Padang Pasir

Terseret Angin Terbakar Panas......

Atau lagu berjudul "Cari Pacar Lagi” (2008) karya band ST 12

Sayangku, sayang padamu

Tak indah seperti dulu

Maumu begini maumu begitu 
Tak pernah engkau hargai aku

I am sorry, ku tak akan love you lagi.

Contoh di atas hanya sebagian kecil dari lagu-lagu dengan lirik bahasa campuran. Pada beberapa contoh tersebut, ditampilkan beberapa lirik lagu dengan campuran bahasa Indonesia sebagai bahasa dominan, dan bahasa Inggris sebagai tambahan.

Lagu bisa dimaknai sebagai bentuk media komunikasi sekaligus produk budaya populer. Sebagai media komunikasi, lagu berperan menjadi media penyampai pesan simbolik dan estetik dari si pengarang kepada pendengar atau penikmatnya. Sebagai produk budaya populer lagu merupakan representasi dari budaya di mana lagu tersebut diciptakan. Salah satu unsur utama dari lagu adalah lirik dengan menggunakan bahasa tertentu.

Hadirnya kosa kata bahasa Inggris dalam penggalan lirik beberapa lagu di atas bisa dimaknai dari beberapa perspektif. Yang pertama, penulis lirik memasukkan kosa kata bahasa Inggris ke dalam lirik lagunya untuk alasan estetis agar rima nada lagu yang dihasilkan terdengar lebih indah. Namun, perpektif tersebut menimbulkan pertanyaan, apakah kosa kata bahasa Indonesia sedemikian miskin sehingga tidak ada pilihan kata yang mampu disematkan untuk menghasilkan rima yang indah di telinga.

Perspektif kedua melihat penggunaan bahasa Inggris pada lirik lagu Indonesia bisa dipandang sebagai bentuk rasa inferior budaya Indonesia terhadap budaya barat (bahasa Inggris) yang dipandang lebih superior. Hal itu sejalan dengan wacana postkolonial bahwa bentuk kolonialisme baru, bukan lagi hadir melalui kolonisasi melainkan dengan cara yang lebih halus dan samar. Salah satunya melalui dominasi budaya termasuk bahasa.

Perspektif ketiga memaknai penggunaan bahasa Inggris ke dalam lirik lagu Indonesia sebagai bentuk usaha proses menuju "go internasional" lagu Indonesia untuk bisa mendapatkan audience yang lebih luas.

Pada perkembangannya, dalam lingkup lokal, ada trend lirik lagu dengan bahasa campuran bahasa daerah (misalnya bahasa Jawa) dengan bahasa Indonesia. Hal itu bisa ditemukan salah satunya pada lagu berjudul "Sayang" ciptaan Anton Obama yang sempat dibawakan oleh grup band NDX A.K.A. Lagu ini menjadi populer setelah dibawakan kembali oleh Via Vallen pada tahun 2015. Penggalan liriknya sebagai berikut:

Sayang,

Opo kowe krungu jerite atiku

Mengharap engkau kembali

Sayang 


\section{Nganti memutih rambutku}

Rabakal luntur tresnoku......

Fenomena bahasa campuran pada lingkup yang lebih lokal, dapat dilihat dengan perspektif yang sama. Pada intinya fenomena tersebut menjadi indikasi adanya pergulatan budaya dalam berbagai dimensi. Salah satu penampakan yang terlihat adalah pada budaya populer, sebagai sarana yang halus dan mudah diterima.

Sejauh ini, tidak ada aturan yang mengharuskan lirik lagu Indonesia harus dalam Bahasa Indonesia, atau lirik lagu harus menggunakan satu jenis bahasa secara konsisten. Pada kenyataannya banyak unsur dalam bahasa Indonesia merupakan serapan dari bahasa asing. Yang menarik terkait dengan maraknya penggunaan bahasa campuran dalam lirik lagu adalah penerimaan dari audience lagu tersebut yang ternyata sebagian besar menerima dengan wajar bahkan baik. Hal itu dibuktikan dengan banyaknya lagu dengan lirik bahasa campuran menjadi hits atau populer.

Bahasa dan kebudayaan tidak hadir terisolasi, tetapi selalu berada dalam pengaruh bahasa dan budaya lain. Oleh karenanya, bahasa dan kebudayaan akan selalu berubah, baik sebagai akibat hubungannya secara internal dengan kelompok-kelompok masyarakat yang membentuknya, maupun karena interaksinya dengan bahasa dan kebudayaan yang lain. Sehubungan dengan ini, tidak dapat dipungkiri bila pada saat ini hampir tidak mungkin ada sebuah bahasa yang sama sekali tidak terpengaruh dari bahasa yang lain.

Bahasa merupakan salah satu unsur kebudayaan yang penting. Sebagai unsur kebudayaan bahasa mampu merepresentasikan perubahan-perubahan sosial yang terjadi di tengah-tengah masyarakat penggunanya. Dinamika pengguna bahasa dapat digunakan sebagai indikator bagaimana dominasi budaya tertentu terhadap budaya yang lain di dalam masyarakat. Poynton dalam (Ida, 2014) menjelaskan bahwa bahasa terdiri atas konteks yang juga secara simultan berhubungan satu sama lain. Dalam tahapan ini, bahasa yang dihasilkan dalam berbagai wujud merupakan hasil budaya yang tidak bisa dilepaskan dari konteks ruang waktu kebudayaan terkait.

Bahasa merupakan bentuk identitas dari budaya masyarakat penggunanya. Menurut Kamus Besar Bahasa Indonesia (KBBI, 2008), salah satu fungsi bahasa adalah memberikan identitas. Menurut (Anshori, 2017), identitas diartikan sebagai jati diri ; beridentitas berarti mempunyai atau mengandung identitas. Tidak ada satu satupun di dunia yang tidak beridentitas. Identitas tersebut dapat terefleksi dalam bentuk lingual yang digunakan 
seseorang. Setiap bahasa memiliki karakteristik yang menjadi penciri (identitas) penutur, terutama dalam hubungannya dengan dengan budaya. Identitas juga merupakan makna penting dari kehadiran individu atau suatu objek dalam kehidupan sosial. Tak ada seorang pun di dunia ini mau kehilangan identitasnya.

Identitas dalam sebuah kebudayan merupakan satu hal yang penting seperti disampaikan oleh (Piliang, 2009) ada persoalan besar tentang batas-batas identitas dalam kebudayaan. Definisi, keberadaan bahkan fondasi bagi 'identitas' itu kini dipertanyakan dalam kecenderungan pencampuran, persilangan dan hibridisasi kebudayaan kontemporer. Apakah identitas kebudayaan masih berpijak pada sebuah fondasi secara konsisten dan kontinu, atau malah fondasi itu sendiri telah runtuh, yang membentuk sebuah arsitektur kebudayaan yang tanpa fondasi (foundationless): sebuah kebudayaan yang mengapung ke sana ke mari, mengikuti angin perubahan yang ada, yang tidak mempunyai ketetapan diri, yang perkembangannya sangat menggantungkan diri pada kekuatan-kekuatan eksternal.

Selain perannya sebagai identitas budaya, bahasa juga memiliki peran lain seperti dijelaskan Habermas dalam (Agustianto, 2013) bicara tentang bahasa sebagai sarana integritas sosial antara berbagai subjek komunikasi dan sarana sosialisasi kebutuhan dan kepentingan yang melatarbelakangi komunikasi itu. Bagi Habermas, bahasa hakekatnya merupakan manifestasi kebutuhan-kebutuhan sosial. Kebutuhan dan kepentingankepentingan sosial yang sebenarnya menentukan struktur dan makna bahasa.

Prularisme permainan bahasa oleh Habermas ditarik ke konteks hakikat komunikasi, dan perkara komunikasi itu pada gilirannya dilihat berpusat pada persoalan kebutuhan dan kepentingan.

Identitas budaya perlu diperhatikan mengingat budaya berkaitan dengan nilai,values, yang terkandung di dalamnya yang mana tidak dapat dengan mudah berubah atau bergeser. Bahasasebagai identitas budaya memiliki hubungan yang erat dengan masyarakat penuturnya sehingga bahasa tidak bersifat netral dari pengaruh dinamika masyarakat dan kebudayaan masyarakat penuturnya. Sehubungan dengan hal itu, Voloshinov dalam (Wijana, 2014) mengatakan bahwa penggunaan bentuk-bentuk kebahasaan dipengaruhi oleh kondisi kemasyarakatan dan interaksi anggota- anggota yang terlibat di dalamnya. Interaksi tersebut bagaikan pertarungan antar kelas-kelas sosial masyarakat bersangkutan:

"The form of signs are conditioned above all by the social organization of the participants involved and also by the immediate conditioned of their 
interaction. Furthermore, sign becomes an arena of the class struggle. In other words the linguistic sign is open to different orientation and evaluation in the social world"

Dalam pergulatan budaya inilah kemudian tampak dominasi kelompok masyarakat yang satu atas kelompok masyarakat yang lain. Kelompok masyarakat dengan "status budaya" yang lebih rendah memandang positif "status budaya" masyarakat yang lebih tinggi sehingga membuka jalan kebudayaannya didominasi oleh kebudayaan lain.

Menurut Lawrence and Wishart dalam (Hanif, 1970) hegemoni bisa didefinisikan sebagai dominasi oleh satu kelompok terhadap kelompok lainnya, dengan atau tanpa ancaman kekerasan, sehingga ide-ide yang didikte oleh kelompok dominan terhadap kelompok yang didominasi diterima sebagai sesuatu yang wajar (common sense). Dalam hegemoni, kelompok yang mendominasi berhasil mempengaruhi kelompok yang didominasi untuk menerima nilai-nilai moral, politik, dan budaya dari kelompok dominan (the ruling party), kelompok yang berkuasa. Seturut dengat itu, Antonio Gramsci dalam (Yusuf, 2016) menjelaskan bahwa istilah hegemoni merujuk kepada sesuatu atau perluasan kekuasaan serta kepatuhan "aktif” dari kelompok yang didominasi oleh kelas yang berkuasa entah itu lewat penggunaan kepemimpinan intelektual, moral dan politik, yang terwujudkan oleh bentuk kooptasi kelembagaan dan manipulasi sistematis atas teks dan tafsirannya.

Menurut McQuaail dalam (Littlejohn, 2018) Hegemoni merupakan dominasi ideologi palsu atau cara pikir terhadap kondisi sebenarnya. Ideologi tidak disebabkan oleh sistem ekonomi saja, tetapi ditanamkan secara mendalam pada semua kegiatan masyarakat. Jadi, ideologi tidak dipaksakan (secara frontal) oleh salah satu kelompok kepada yang lain, tetapi bersifat persuasif dan masuk melalui alam bawah sadar. Kebudayaan dominan menghidupkan minat tertentu melalui budaya populer kepada kebudayaan yang didominasi. Media dan teknologi memiliki peran yang besar dalam proses penetrasi atau infiltrasi kebudayaan tersebut. Terkait dengan itu, bentuk-bentuk dominasi budaya bisa hadir dalam bentuk yang halus dan samar. Seringkali cara yang digunakan adalah melalui produk-produk budaya populer, dalam hal ini melalui bahasa campuran dalam lirik lagu.

Secara etimologis, istilah budaya populer berasal dari bahasa Latin yakni cultura popular. Istilah ini dapat diartikan sebagai budaya masyarakat (orang-orang) biasa. Adapun jika melihatnya dari segi terminologis menurut Adorno dan Marcuse dalam Yusuf (Yusuf, 
2016), Budaya populer dimaknai sebagai budaya massa yang dihasilkan oleh industri budaya; yang tujuannya tak lain untuk menjamin stabilitas dan kesinambungan kapitalisme. Dengan kata lain menurut kedua tokoh tersebut, budaya populer atau massa muncul akibat dari massifikasi industrialisasi dan komersialisasi yang berorientasi kepada keuntungan yang sebesar-besarnya. Baker dalam (Rakhmawati, 2016) menambahkan bahwa dalam kajian budaya (cultural studies) secara umum memahami budaya popular sebagai tempat dimana terjadi konsensus-konsensus relasi kuasa (power) dengan konsep ideologi dan hegemoni. Dalam kaitannya dengan kekuasaan, budaya popular pada akhirnya dijadikan "alat" untuk mendapatkan, melanggengkan atau menutup kekuasaan lainnya. Budaya popular dengan ciri yang khas seperti: tema yang sederhana, diproduksi secara massal serta beragam enti-tas mempunyai kesempatan yang sama untuk mengaksesnya maka, posisi strategis budaya popular dalam memobilisasi konsensus relatif dapat diandalkan.

Penggunaan bahasa campuran dalam lirik lagu bisa dimaknai tidak semata-mata bentuk dominasi budaya yang lebih "kuat" terhadap budaya yang lebih "lemah" namun bisa juga menjadi sebuah perlawanan yang "lemah" terhadap yang "kuat". Dalam hal ini bisa kita lihat penggunaan bahasa Indonesia dalam lirik lagu Jawa seperti contoh di atas sebagai bentuk perlawanan budaya Jawa terhadap budaya yang lebih "kuat". Basso dalam (Wijana, 2014) mengemukakan bahwa resistansi, seperti halnya dominasi, tidak dapat diperkirakan, disadari, atau tampak jelas. Bentuk resistansi yang paling efektif adalah perlawanan-perlawanan yang dilakukan dengan bentuk yang lain. Dapat dilihat pada tayangan-tayangan sinetron, FTV atau semacamnya, budaya Jawa sering kali ditampilkan inferior melalui karakter dan peran yang minor. Terlepas dari berhasil atau tidak bentuk perlawanan tersebut, dapat dilihat bahwa lagu bahasa Jawa dengan campuran bahasa Indonesia mendapat penerimaan yang baik dari masyarakat luas. Hal tersebut didukung dengan penyebaran budaya populer yang lebih cepat dan masif melalui teknologi informasi (internet dan media sosial).

Dari pembahasan di atas dapat difahami bahwa penggunaan bahasa campuran dalam lirik lagu merupakan cermin dari terjadinya pergulatan kebudayaan dalam bentuk hegemoni dan resistansi kebudayaan. 


\section{KESIMPULAN}

Dari penelitian ini bisa difahami adanya pergulatan budaya dalam berbagai dimensi antara budaya "superior" terhadap budaya "inferior". Dominasi dan hegemoni terjadi secara simbolik melalui budaya populer secara halus sehingga mudah diterima. Salah satu bentuk budaya populer yang digunakan adalah lagu dengan lirik menggunakan bahasa campuran.

Sejauh ini penggunaan bahasa campuran pada lirik lagu diterima sebagai suatu hal yang wajar. Dari sudut pandang postmodernisme identitas entitas budaya bisa jadi tidak terlalu menjadi permasalahan yang mendasar seiring dengan penghargaan atas keragaman dan lokalitas yang dijunjung. Namun, jika dikaji lebih jauh fenomena penggunaan bahasa campuran bisa jadi merupakan bentuk halus dari dominasi dan hegemoni budaya satu terhadap yang lain. Dari situ diharapkan para pelaku budaya (populer) agar lebih arif dalam menggunakan simbol-simbol budaya dalam produk budaya yang dihasilkan. Semoga fenomena tersebut tidak menjadi bahaya laten bagi harmoni keragaman budaya yang ada.

\section{DAFTAR PUSTAKA}

Agustianto, A. (2013). Komunikasi Dalam Dominasi Budaya Teori Kritis Menurut Jurgen Habermas. Jurnal Ilmu Budaya. 9 (2):75.

Anshori, D. S. (2017). Etnografi Komunikasi : Perspektif Bahasa. PT Rajagrafindo Persada.

Hanif, M. (1970). Studi Media Dan Budaya Populer Dalam Perspektif Modernisme Dan Postmodernisme. KOMUNIKA: Jurnal Dakwah Dan Komunikasi. 5 (2): 235-251. https://doi.org/10.24090/komunika.v5i2.174

Ida, R. (2014). Metode Penelitian Studi Media dan Kajian Budaya. Prenadamedia Group.

Kriyantono, R. (2014). Teknik Praktis Riset Komunikasi. Kencana Prenadamedia Group.

Littlejohn, S. W. (2018). Teori Komunikasi. Salemba Humanika.

Lubis, A. Y. (2014). Postmoderinsme Teori dan Metode. PT Rajagrafindo Persada.

Nurhadi, Z. (2017). Teori Komunikasi Kontemporer. PT Balebat Dedikasi Prima.

Piliang, Y. A. (2009). Retakan-retakan Kebudayaan: Antara Keterbatasan dan Ketakberhinggaan. Melintas.

Rakhmawati, Y. (2016). Hibriditas New Media Komunikasi dan Homogenisasi Budaya. Komunikasi, $X$. 
Ridaryanthi, M. (2014). Bentuk Budaya Populer dan Konstruksi Perilaku Konsumen Studi Terhadap Remaja. Visi Komunikasi, 01.

Ronda, M. (2018). Tafsir Kontemporer Ilmu Komunikasi: Tinjauan teoritis, Epistemologi, Aksiologi . Indigo Media.

Sugiyono. (2009). Metode Penelitian Kuantitatif dan Kualitatif $R \& D$. Alfabetae.

Wibowo, W. (2001). Manajemen Bahasa. Gramedia Pustaka Utama.

Wijana, I. D. P. (2014). Bahasa, Kekuasaan, Dan Resistansinya: Studi Tentang Nama-Nama Badan Usaha Di Daerah Istimewa Yogyakarta. Humaniora, 26.

Yusuf, A. (2014). Postmodernisme: Teori dan Metode. PT Rajagrafindo Persada.

Yusuf, A. (2016). Pemikiran Kritis Kontemporer: Dari Teori Kritis, Cultural Studies, Feminisme, Postkolonial Hingga Multikulturalisme. PT Rajagrafindo Persada. 